\title{
The Impact of Career Concerns and Cognitive Dissonance on Bureaucrats' Use of Benefit-Cost Analysis
}

\author{
Johanna Jussila Hammes ${ }^{1}$ (D)
}

Accepted: 4 August 2021 / Published online: 21 August 2021

(c) The Author(s) 2021

\begin{abstract}
Previous research shows that Benefit-Cost Analysis (BCA) is seldom done in Sweden, and that the results e.g., in Norway and the Netherlands do not influence the ultimate policy choice. We explain why bureaucrats may choose (not) to do a BCA with cognitive- and search costs coupled with career concerns. Given the initial policy chosen by an agenda setter, bureaucrats who stay working at an agency have policy preferences close to the initial policy; those with reservation wages above a threshold quit and therefore do not influence policy. The bureaucrats' preferences converge to the initial policy level over time. A BCA reveals the inefficiency of the initial policy and the bureaucrats consequently have no incentive to do one, except when the policy is restricted by a binding governmental budget constraint.
\end{abstract}

Keywords Bureaucrats - Career concerns · Civil servants $\cdot$ Cognitive dissonance $\cdot$ Benefitcost analysis $\cdot$ Environmental policy $\cdot$ Information search

JEL Classification D61 $\cdot$ D73 $\cdot$ H41

\section{Introduction}

Why are benefit-cost analyses (BCA) either not made at all in conjunction with energy, environmental and climate policy (in Sweden) (Samakovlis \& Vredin Johansson 2005; 2007; Pyddoke \& Nerhagen 2010; Broberg, et al. 2010; Hansson \& Nerhagen 2019; Forsstedt 2018; Hansson 2019), or when made (e.g., in Norway and the Netherlands, and in conjunction with transport infrastructure investments in Sweden), the results are ignored when policy-decisions are made (Welde et al. 2013; Sager \& Ravlum 2005; Sager 2016; Annema et al. 2017)? ${ }^{1,2}$

\footnotetext{
1 The literature recognizes some exceptions to the latter rule, e.g., Eliasson and Lundberg (2011) show that while the Swedish bureaucrats' ranking of national transport infrastructure projects broadly speaking follows the recommendations from the BCA, the politicians' ranking is not influence by it. Welde et al. (2013) show that while the BCA results influence the overall project ranking in Sweden, no such effect can be found in Norway.

${ }^{2}$ In this paper, BCA is used as an overarching term for all types of methodologies that attempt to quantify

Johanna Jussila Hammes

johanna.jussila.hammes@vti.se

1 Swedish National Road and Transport Research Institute, VTI, Box 55685, 10215 Stockholm, Sweden
} 
The most recent summary of the use of BCA by 26 Swedish government agencies involved in environmental policy-making (Swedish Environmental Protection Agency 2020) covers 275 analyses of policies and policy instruments over the period 2008-2019. Out of all analyses, 29 (about 11 per cent) contain a cost analysis, and 52 (about 19 per cent) a full BCA.

The case for doing a BCA ahead of governmental regulation is strong, however. For instance, Rose-Ackerman (2007, p. 23) notes that a BCA constitutes "a reasonably clear standard that can make special interest deals harder to accomplish, without tying the hands of the state." Moreover, she notes that BCA is superior to, e.g., the precautionary principle, as this principle is not defined clearly enough to provide realistic policy guidance. Cass Sunstein has long argued for the use of BCA, e.g., in terms of "thinking slow", i.e., that a $\mathrm{BCA}$ reduces at least two common fallacies of thinking, namely the framing effect and loss aversion (Sunstein 2000, 2019). Hahn and Tetlock (2008) give examples where a BCA has played an important role in American environmental regulation, e.g., in the phasing out of lead in gasoline. They also give examples of regulations where the costs probably exceeded the benefits. Bondemark et al. (2020) study the impact of alternative analyses, namely the distributional and goal fulfilment analyses on the choice of transport infrastructure projects in Sweden. They note that interviewed planners have concerns about the way these analyses are designed, that the analyses lack nuance, and that there is no consensus on how to perform the analyses. A BCA performs better on all these aspects and is consequently one of the three main factors that influences investment decisions. ${ }^{3}$ While a BCA does not guarantee that a chosen policy is either efficient or cost efficient, it reduces the risk of imposing a proposal that is inefficient or leads to sub-optimisation (Nerhagen \& Forsstedt 2019).

The literature contains a number of explanations to why BCA does not influence policymaking more. These include political economics including ideology, ${ }^{4}$ equity concerns, the cost of conducting a BCA (Vigren \& Ljungberg 2018), ${ }^{5}$ the organization of government agencies (Shapiro 2017), and possibly more seldom, geographical considerations (Halse \& Fridstrøm 2019). The present paper offers a micro-level explanation instead. Thus, cognitive dissonance and bureaucrats' career concerns lead them to self-select to implement an agenda setting policy instead of socially optimal policy. ${ }^{6}$

An important premise for this hypothesis is that bureaucrats have real authority (Aghion \& Tirole 1997) and can influence policy design (Faber et al. 2002; Uba 2010; Berkowitz \& Krause 2020). Moreover, while e.g., Dewatripont et al. (1999) point out that a distinguishing feature between government agencies and private companies is that the former are instructed to pursue social welfare objectives and the latter are asked solely to maximize shareholder value, Gregg et al. (2011) show that individuals self-select themselves so that the more prosocial individuals will, to a greater degree, work for the non-profit sector (for an overview of the prosocial behavior among bureaucrats, see Polidori and Teobaldelli (2013)). Lindvall and

\footnotetext{
Footnote 2 (continued)

both the benefits and the costs of policy, from an ordinary BCA to Regulatory Impact Assessment, Social Choice Valuation, Participatory Value Evaluation, Deliberative Monetary Valuation, etc.

3 The other two are negative non-valued environmental effects and the assessment of the total socio-economic impact.

${ }^{4}$ For example, Nyborg (1998) and Mouter (2017a, b; Mouter et al. 2013) have interviewed politicians and decision-makers about their views about BCA.

5 Vigren and Ljungberg (2018) note that Public Transport Authorities in Sweden do not use BCA as a means for decision support, but that the cost of doing one is not a reason for this. Rather, they lack knowledge, and rely on other types of decision support.

6 Besides explaining why a BCA is not done and/or used, the present model could also be used to explain why other analyses, such as an environmental impact assessment, not always get done.
} 
Rothstein (2006, p. 52) argue that "since the 1980's [in Sweden], a large number of national administrative agencies have been set up with ideology production as their main aim"-a view that combined with Gregg's et al. (2011) indicates that public policy may be more "prosocial" than would be socially optimal. Brady et al. (1995) integrate the theory of cognitive dissonance with public choice theory in a context where the public sector acts as a market surrogate for the exchange of dissonance. They argue that cognitive dissonance can be used as a framework for examining certain public sector decisions, which will provide insight into unseen elements of rent-seeking.

Cognitive dissonance is the "uncomfortable feeling caused by simultaneously holding two contradictory cognitions" (Alfnes et al. 2010, p. 147). An important feature of cognitive dissonance is that the dissonance arousing behaviour must be perceived as having been freely chosen, having little external justification, and entailing a commitment (Akerlof \& Dickens 1982; Nail et al. 2004; Wichardt 2012). Cognitive dissonance can then be seen as a price for norm violations. Moreover, different people have different "reservation prices" for norm-disobedient behaviour in the same or similar situations (Wichardt 2012). A bureaucrat may then experience cognitive dissonance if they have to promote a level of public good provision that differs from their preferred one, regardless of whether this preference is based on a professional norm, a private belief, a mission (Besley \& Ghatak 2005) or the bureaucrat's belief of what is socially optimal (Eggert et al. 2018). As stated originally by Festinger (1957), cognitive dissonance theory proposes that the bureaucrat is motivated to reduce this tension and may, in the context of the present paper, achieve this either by adapting their own preferences towards the agency's goal policy, or by changing jobs (quitting). We show that because of the cognitive adjustment that an individual experience over time, the rent obtained from being employed by a given agency increases over time. However, the longer the individual remains employed by the agency, the lower is their propensity to do a BCA that might challenge the agency's preferred policy choice. Only in agencies whose supply of the public good is restricted by a binding governmental budget constraint may the bureaucrats have an incentive to do a BCA, given that it may influence the budget constraint.

While cognitive dissonance is widely studied, the literature on the impact of cognitive dissonance on bureaucrats' behaviour is not large. Brady et al. (1995) explain how public sector agents can use the manipulation of dissonance for their own ends to achieve their own goals by changing the perceptions of the public. Unlike the present paper they do not consider how the cognitive dissonance experienced by the bureaucrats themselves influences their behaviour. Konow (2000) examines the cognitive trade-off arising from a public agent either forwarding their own material utility or "fairness". Using variations of the so-called "dictator game" his experiments corroborate both the fairness and cognitive dissonance components and show that "unfair" behaviour may be attributed rather to self-deception than to unadulterated self-interest.

The present paper is organized as follows: In the next section we construct a theoretical model of the economy and the bureaucrats. Policy outcomes from the model with cognitive dissonance are presented in Sect. 3. Section 4 extends the model to explain the incentives for some agencies to conduct a BCA by including a governmental budget constraint in the model. The last section discusses the results and concludes. 


\section{The Model}

We assume that individuals maximize welfare, which can be aggregated into social welfare by using a utilitarian welfare function with equal weights given to all individuals. We build on a career concerns model based on Alesina and Tabellini (2007) and on a model of cognitive dissonance by Acharya et al. $(2015,2018)$. The basic assumption of the model is that an individual bureaucrat can influence public decision-making, i.e., that an individual bureaucrat has real authority (Aghion and Tirole (1997); for decision-making in American states, Berkowitz and Krause (2020), for an empirical investigation of German environmental administrators, Faber et al. (2002) or a study of who formulates Swedish environmental and energy policy, Uba (2010)). We further assume that the bureaucrats are influenced by professional norms (Wilson 1989), or a "mission" (Besley \& Ghatak 2005), the formation of which we do not model. A final assumption is that a BCA, if made by the bureaucrats, will reveal the true social welfare; there is no uncertainty, and the BCA is assumed to be "perfect". This is a simplifying assumption, the relaxation of which would not change the model's main predictions.

\subsection{The Economic Background}

Consider an economy consisting of $H$ individuals denoted by superscript $h=\{1,2, \ldots, H\}$. There is a private good, $z$, and individuals also derive utility from a non-rival and non-excludable public good, $g$, the utility function being $q^{h}(g) \geq 0$. We arrange the population in the order of their preferences for the public good so that $q^{1}<q^{2}<\cdots<q^{H}$. Utility from the public good is assumed to be increasing and concave in $g$, i.e., $q_{g}>0, q_{g g}<0$, the subscripts denoting differentials. We assume utility from public good consumption to be normally distributed in the population with a mean $\bar{q}$ and variance $\sigma_{q}^{2}: q^{h}(g) \sim N\left(\bar{q}, \sigma_{q}^{2}\right)$. We assume quasi-linear utility with additively separable preferences. Normalizing the price of the private good $z^{h}$ to one, utility takes the form $u^{h}=z^{h}+q^{h}(g)$.

The government determines public good supply. The provision of the public goods is costly, the cost being given by $c^{g}(g)$. We assume the cost function to be strictly convex, i.e., $c_{g}^{g}(g)>0$ and $c_{g g}^{g}(g)>0$.

We assume that the cost of public good provision is borne entirely by the taxpayer, who pay for the provision in equal shares: $c^{g}(g) / H$. An individual earns an income gross of effort, equal to $r^{h}$, with the consumption of the private good being equal to $z^{h}=r^{h}-c^{g}(g) / H$. An individual's indirect utility is then given by

$$
v^{h}(g)=r^{h}+q^{h}(g)-\frac{c^{g}(g)}{H}
$$

Summing indirect utilities over all individuals yields aggregate welfare:

$$
W(g) \equiv R+Q(g)-c^{g}(g),
$$

where $R$ is the aggregate income and $Q(g)$ is the aggregate welfare from public good consumption. Solving for the socially optimal level of provision, denoted by $g^{*}$ we maximize Eq. (2) with respect to (w.r.t.) to the policy choice, $g$. This yields the familiar condition: 


$$
Q_{g}\left(g^{*}\right)=c_{g}^{g}\left(g^{*}\right)
$$

i.e., the aggregate marginal benefit from the consumption of the public good must equal the marginal cost of producing the good.

\subsection{Bureaucrats}

$J \ll H, J \in H$ bureaucrats in a government agency or ministry prepare a background analysis and a proposal for policy $g .{ }^{7,8}$ Consider a bureaucrat $j \in J$ with a normally distributed starting attitude $q^{j 0}\left(g^{j 0}\right) \sim N\left(\bar{q}^{J 0}, \sigma_{q^{j 0}}^{2}\right)$, where the superscript 0 denotes a starting attitude, which is fixed (given originally by the professional norm), the mean attitude among bureaucrats being $\bar{q}^{J 0}$ and the variance $\sigma_{q^{j 0^{*}}}^{2}$

The bureaucrat may be confronted with cognitive dissonance because the organizational goals of the government agency or ministry may differ from the bureaucrat's professional norms. In order to have a career, they will not only have to exert effort $\left(e^{j}\right)$, but may also need to adjust their professional norm, which is costly. This adjustment is voluntary, however, since the bureaucrat could always choose the exit option (quit). ${ }^{9}$ An example of cognitive dissonance experienced by a bureaucrat might involve an economist, who believes that policy choice should be influenced both by the costs and the benefits of a policy to the society as a whole, and an ecotoxicologist who wants to minimize the impact of emissions on some biota. If the agency's organizational goal is biased in either direction, either the economist or the ecotoxicologist may either adjust their professional norm towards the organizational goal or find a new job.

The bureaucrat takes a policy action $g^{j}$ that maximizes an attitude function $\pi\left(q(g), q^{j 0}\left(g^{j 0}\right)\right)$. The action $g$ may in some circumstances be chosen by the individual but

\footnotetext{
7 The final decision may still be made by politicians motivated by re-election and may deviate from the one proposed by the bureaucrats.

8 In Sweden, the background analyses concerning the use of BCA are regulated by three laws: 1st Chapter, $3 \S$ of the National budget law (Budgetlagen 2011:203), the Authority regulation (Myndighetsförordning 2007:515), and the Ordnance on impact assessment in regulation (Förordning (2007:1244) om konsekvenskutredning vid regelgivning). These stipulate that consideration must be taken of costs to the state and to firms, but not to individual citizens or the society as a whole. Other types of analyses are also required, e.g., an environmental impact assessment according to the Environmental code (Miljöbalken 1998:808, 6th Chapter) and the Environmental assessment procedure (Miljöbedömningsförordning 2017:966).

9 The mechanism here resembles closely that in Akerlof and Dickens (1982), who exemplify cognitive dissonance with workers in hazardous industries. These workers, too, choose to stay at their jobs despite cognitive dissonance, reducing this dissonance over time by convincing themselves of their work not being so hazardous after all. According to Meyer et al. (1993, p. 539) "[e]mployees with a strong affective commitment [to their job] remain with the organization because they want to, those with a strong continuance commitment remain because they need to, and those with a strong normative commitment remain because they feel they ought to do so." Brösamle and Norström Skans (2011) present a dataset containing about 75,000 individual bureaucrats over 24 years in Sweden. Their data indicates that 14.18 percent of the bureaucrats had a job in the private sector in their role previous to the present one. 20.07 percent worked in the noncommercial/non-governmental sector in their previous job. The data set does not contain information about bureaucrats leaving the public sector, however. Suzuki and Hur (2020) in turn compare the commitment of bureaucrats in relatively open civil service systems which, among other attributes, have flexible entry into the service with career mobility of public officials between public and private sector, with more closed civil service systems. Their dataset consists of 20 European countries, of which they classify Sweden, Finland, the UK, Denmark, Estonia, and the Netherlands as "open" systems. Rothstein (2016) notes that in at least Australia, Canada, and Sweden it is easy for employees to move between the private and the public sectors.
} 
may also be assigned by the employer (e.g., through a collegial way of decision-making, by a chief, political orders, existing law etc.). The policy outcome based on function $\pi$ and effort, $e^{j}$, is given by:

$$
g=\pi\left(q(g), q^{j 0}\left(g^{j 0}\right)\right)+e^{j},
$$

Attitudes and effort are assumed to be additive.

Suppose that the maximizer of $\pi\left(q(g), q^{j 0}\left(g^{j 0}\right)\right)$ over $X \subseteq \mathbb{R}^{n}$ is unique and let $g^{\max }$ denote it. In the case that the action is assigned it differs from the professional norm, $g^{\max } \neq g^{j 0}$. Then, the action taken is exogenous to the individual's preferences (Acharya et al. 2015, p. 5). ${ }^{10}$ Then, the decision-maker experiences a cognitive dissonance cost, and may want to change their attitude from $g^{j 0}$ to a new attitude $g^{j t}$, with $\left|g^{j 0}-g^{\max }\right|>\left|g^{j t}-g^{\max }\right|$. Changing attitudes is costly. Denoting the strictly convex and increasing cost of changing the attitude by $\delta\left[e^{j}\left(\left|g^{j 0}-g^{j t}\right|\right)\right]$, and the likewise strictly convex and increasing cognitive dissonance cost by $d\left[e^{j}\left(\left|g^{j t}-g^{\max }\right|\right)\right]$, the intensity of the discomfort increases with the discrepancy between the individual's initial attitude and the behavior that they have executed. Note that both cognitive costs are functions of effort, $e^{j}$. A bureaucrat strives to minimize the cognitive costs.

The bureaucrat faces the following participation constraint:

$$
\mathrm{E}\left[r\left(e^{j}\right)\right]-c^{e}\left(e^{j}\right) \geq 0
$$

where $r\left(e^{j}\right)$ is the gross reward function and $\mathrm{E}$ denotes unconditional expectations over effort, $e^{j}$. Effort at work is costly, and this strictly convex and increasing cost is labelled $c^{e}\left(e^{j}\right)$. We define $c^{e}\left(e^{j}\right)$ below. A bureaucrat whose participation constraint is not met will not be interested in staying at their job.

The timing of events is as follows. A bureaucrat has a professional norm denoted by $g^{j 0}$. They get employed by a government agency with a policy goal given by $g^{A}$. This policy goal may or may not be equal to the socially optimal policy. Next, the bureaucrat chooses effort, $e^{j}$, and simultaneously, if the bureaucrat's professional preferences do not coincide with the agency's policy goals, they experience cognitive dissonance and may choose to change their professional norm. Finally, outcomes are observed, and the reward is paid. Only the outcome $g$ is observed by the principals, not its composition between effort and attitudes. Hence the agent's reward can be based only on the policy outcome, $g$.

\section{Policy Outcome with Cognitive Dissonance}

\subsection{Choice with Cognitive Dissonance}

The goal policy (i.e., the agenda setting policy level) facing the bureaucrat is thus denoted by $g^{A}$. Assume that the goal policy level of public good provision always differs from the socially optimal level of provision.

Given that $g^{A}$ is the relevant measure of performance with which the bureaucrat is evaluated, their reward gross of effort is assumed to be (Alesina \& Tabellini 2007, p. 171):

\footnotetext{
10 The case where the bureaucrat's preferences exactly match those of the employer, i.e., when $g^{\max }=g^{j 0}$, is trivial.
} 


$$
r\left(e^{j}\right)=\omega \mathrm{E}\left\{E\left[\pi\left(q\left(g^{A}\right), q^{j 0}\left(g^{j 0}\right)\right) \mid g^{A}\right]\right\}
$$

where $\omega$ is the market value of the bureaucrat, and $E$ denotes expectations over $\pi$, conditional on the realization of $g$. The bureaucrat's career prospects are thus a function of their attitude function $\pi$. Denoting the public's perception of effort, $e^{j}$, by $e^{\mathrm{E} j}$ and using Eq. (4), we can write the bureaucrat's reward function as

$$
r\left(e^{j}\right)=\omega \mathrm{E}\left[g^{A}-e^{\mathrm{E} j}\right]=\omega \mathrm{E}\left[\pi\left(q\left(g^{A}\right), q^{j 0}\left(g^{j 0}\right)\right)+e^{j}-e^{\mathrm{E} j}\right] .
$$

We assume that the effort put into work by a bureaucrat is a function of the goal policy level, of their initial attitudes and of the exertion required to change attitudes, so that $e^{j} \equiv e^{j}\left(g^{A}, g^{j 0}, g^{j t}\right)$. We define the effort cost function as:

$$
c^{e}\left(e^{j}\right)=s\left[e^{j}\left(\left|g^{j 0}-g^{A}\right|\right)\right]+d\left[e^{j}\left(\left|g^{j t}-g^{A}\right|\right)\right]+\delta\left[e^{j}\left(\left|g^{j 0}-g^{j t}\right|\right)\right] .
$$

$s$ is the search cost function, which is greater the larger the discrepancy between the imposed policy, $g^{A}$ and the preferred policy, $g^{j 0}$. The search cost function is assumed to be strictly convex and increasing in the distance between the optimal policy and the bureaucrat's preferred policy. Besides the search cost, the cost of effort is also a function of the remaining cognitive dissonance cost $(d)$, and of the cognitive adjustment cost $(\delta)$. If the action $g^{A}$ could be chosen freely by the bureaucrat, both the cognitive dissonance cost and the cost of changing attitudes would be trivially zero. The same applies if $g^{j 0}=g^{A}$. The greater the discrepancy between the $g^{A}, g^{j 0}$ and $g^{j t}$, the greater is $e^{j}$ and the higher the effort cost.

A revenue maximizing and effort minimizing bureaucrat maximizes their welfare given by Eq. (1) with respect to $e^{j}$. Using the participation constraint, Eq. (5), substituting in Eqs. (6) and (7), we can solve for the bureaucrat's reservation wage $\omega$ as:

$$
\omega=s_{e}\left[e^{j}\left(\left|g^{j 0}-g^{A}\right|\right)\right]+d_{e}\left[e^{j}\left(\left|g^{j t}-g^{A}\right|\right)\right]+\delta_{e}\left[e^{j}\left(\left|g^{j 0}-g^{j t}\right|\right)\right] .
$$

The reservation wage thus equals the bureaucrat's marginal cost for effort and varies between individuals. Note that the socially optimal level of public policy provision does not enter Eq. (8).

If the bureaucrat's initial preference for policy equals the goal policy, then $\omega=s_{e}(0)$. This is the true value of the bureaucrat to their employer.

When the bureaucrat's initial preference for public good provision differs from the agenda setting policy, that is, $g^{j 0} \neq g^{A}$, the market value of the bureaucrat differs from the true value to the employer. Doing comparative statics on Eq. (8) yields the following proposition which elaborates on the changes to a bureaucrat's market value as their initial preferences vary:

Proposition 1 The further away from the agenda setting policy $g^{A}$ a bureaucrat's initial attitude $\left(g^{j 0}\right)$ is, the higher is their reservation wage.

Proof Totally differentiating (8) with respect to the bureaucrat's initial attitude, $g^{j 0}$, yields the proof of Proposition 1: 


$$
\frac{d \omega}{d g^{j 0}}=s_{e e}+\delta_{e e}>0
$$

Since we have assumed the cost functions to be strictly convex, the second order conditions are positive. The reservation wage then increases as $g^{j 0}$ shifts further away from the goal policy in either direction, upwards or downwards. A change in the bureaucrat's initial attitude in the direction of the goal policy thus lowers their salary request.

While we described $\omega$ above as the market value of the bureaucrat, in Proposition 1 we have solved for the bureaucrat's reservation wage. This is because a bureaucrat maximizing their own welfare will require at least this level of salary in order to satisfy their participation constraint, Eq. (5).

A bureaucrat with deviating preferences compared to the goal policy cannot reasonably be rewarded for this, however. While the government agencies may have a policy of setting "individual salaries," there is a definite limit to how much an agency would be willing to pay. Assuming that all bureaucrats are paid the same salary, we formulate the following proposition:

Proposition 2 The marginal bureaucrat employed by a government agency will earn their reservation wage, given by Eq. (8). All other bureaucrats will be earning economic rent which is the difference between the marginal bureaucrat's salary and their own reservation wage.

Proof The proof relies on the assumption that preferences among bureaucrats are distributed according to $q^{j 0} \sim N\left(\bar{q}^{j 0}, \sigma_{q^{j 0}}^{2}\right)$ and that $J>1$. The agency will then have to pay a wage higher than the above-defined "true value of the bureaucrat," $\omega=s_{e}(0)$ to the marginal bureaucrat. The other bureaucrats whose participation constraint, Eq. (5), is satisfied will have a reservation wage at most as high as the marginal individual's reservation wage. They will then be earning an economic rent equal to the difference between the reservation wage of the marginal bureaucrat and their own reservation wage.

A corollary of Proposition 2 is that the agency prefers employing bureaucrats with attitudes closely aligned with the agency's goal policy. Rothstein (2016) gives examples of this type of recruitment to Swedish governmental agencies, namely to the National Board for Health and Welfare.

The result in Proposition 2 will of course be modified if the employer can implement "individual wages," knows the bureaucrats' preferences, and is thereby able to discriminate among the bureaucrats. Then, the bureaucrat with preferences closest to $q^{A}$ will get the lowest salary, despite being the most valuable of the bureaucrats from the employer's point of view.

The results in Propositions 1 and 2 can also be used to rationalise the lacking use of BCA. This is illustrated in Fig. 1 Assume that the goal supply of the public good is set at a level differing from the social optimum as above, $g^{A} \neq g^{*}$. Bureaucrats are recruited to implement this policy. Those bureaucrats that stay at the job are those with preferences similar to the goal policy, with a reservation wage below or equal to that given by Eq. (8). A BCA would challenge the initial policy by demonstrating that the socially optimal supply of the public good is different from the present level. The bureaucrats whose preferences are congruent with the goal policy would suffer from 


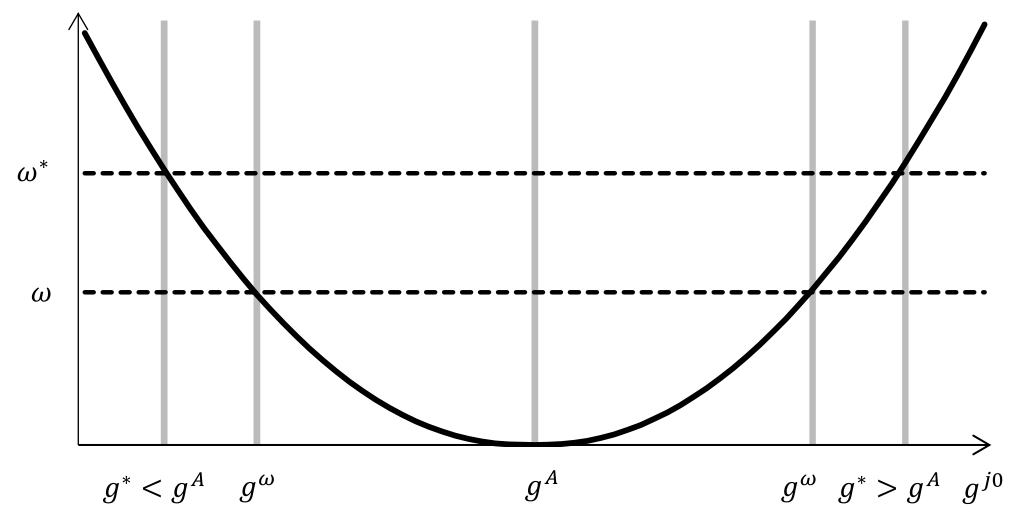

Fig. 1 The thick black curve shows a bureaucrat's reservation wage given their initial professional norm, $g^{j 0}$ and the agenda-setting policy $g^{A}$. Two possible social optima have been drawn, one below and one above $g^{A}$. A bureaucrat with $g^{j 0}=g^{A}$ would require a salary of $\omega^{*}$ to be willing to implement the socially optimal policy $g^{*}$. At the going wage $\omega$, the agency will be able to hire and retain bureaucrats up to point $g^{\omega}$ but not the ones willing to implement $g^{*}$

cognitive dissonance from having to implement the socially optimal policy, and consequently, they have no incentive for doing a BCA.

\subsection{The Stability of the Agenda Setting Policy}

The goal policy $g^{A}$ is not necessarily stable. Starting with an examination of the dynamic development of a bureaucrat's professional norm over time yields the bureaucrat's longterm equilibrium norm for public good provision. We do not construct a formal model but note that at period $t=0$, the bureaucrat has the professional preference for public good supply given by $q^{j 0}$. By period $t=1$, this has changed according to Eq. (7) so that $q^{j 0} \leq q^{j 1} \leq q^{A}$ (or $q^{A} \leq q^{j 1} \leq q^{j 0}$ if the bureaucrat's preferences exceed the goal level of public good provision). At the next decision-making time, the bureaucrat again minimizes costs according to Eq. (7), again adjusting their professional norm closer to the agenda setting level, but still suffering from some cognitive dissonance cost, thus reaching a norm level given by $q^{j 0} \leq q^{j 1} \leq q^{j 2} \leq q^{A}$ (alternatively $q^{A} \leq q^{j 2} \leq q^{j 1} \leq q^{j 0}$ ). Over time, therefore, the bureaucrat's professional preferences will approach the goal level of public good provision. This mechanism is in line with, e.g., the one described by Akerlof and Dickens (1982) for workers in a hazardous industry.

The second dynamic aspect concerns the agency's possibilities for recruitment. We illustrate this with the help of Fig. 2, where we have for simplicity assumed that the agenda setting policy level exceeds the socially optimal policy, i.e., $g^{A}>g^{*}$. The thick black line in the figure depicts the normal distribution of preferences for the public good policy among the entire population, and the solid grey distribution function is the density function for the sub-population of bureaucrats. $g^{*}$ denotes the social optimum and $g^{A}$ the agenda-setting level of public good provision. The grey shaded area marks the bureaucrats whose reservation wage is lower or equal to that given by Eq. (8), denoted by the horizontal line $\omega$.

The instability of $g^{A}$ arises from the recruiting possibilities of the governmental agency. Given that the bureaucrats are recruited from the general population, the probability of recruiting a person with a professional norm closer to the social optimum is higher than the 


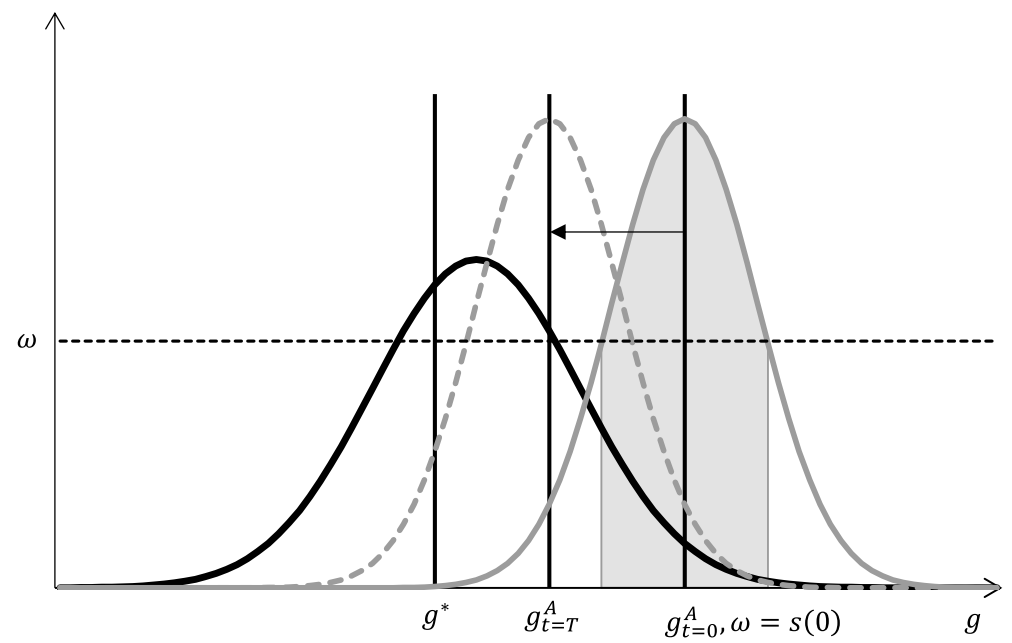

Fig. 2 The instability of $g^{A} \neq g^{*}$ due to recruitment possibilities

probability of recruiting a person further away from the social optimum than $g^{A}$. In fact, this indicates that the bureaucrats' preferences are not normally distributed but that the density function is skewed towards the population mean. If this is the case, over time, the distribution of the bureaucrats' professional norms may move towards the socially optimal policy, marked by the dashed distribution line in Fig. 2. These dynamics may drive the agenda setting (or target) level of public good provision towards the socially optimal level of provision.

If the social optimum lies "on the other side" of the maximum density of the distribution function, the maximum density may be the closest to the social optimum that the policy may move. Thus, the maximum density level of preferences is a stable equilibrium policy optimum. Regardless of the costs of the policy, it is difficult to reach another stable optimum policy.

The recruitment-driven dynamic may however be negated by the first-analysed dynamic for a bureaucrat's cognitive adjustment. The first dynamic is the stronger the lower the level of employee turnover. It would then be expected that the older employees' professional norms have adjusted and lie very close to the agenda setting level; adding a few new recruits will not change this balance. ${ }^{11}$

An additional dynamic aspect is linked to the promotion structure of bureaucracies (Kingston 2002). While our model does not include the promotion structure, Kingston argues that the only serious reward for a bureaucrat lies in promotion within the bureaucracy. While this is not the case in all countries (see footnote 8), it leads to the bureaucrats becoming dependent on their employer. Two alternatives then arise: either the bureaucrats quit and take employment somewhere else (which would be the case if their participation

\footnotetext{
11 The question of professional norms is also of interest here. If, for instance, the agency attempts to recruit bureaucrats with a professional norm closer to the social optimum, the first, cognitive dissonance effect still may outweigh the recruitment effect. Moreover, new recruits with very different professional norms compared to the agenda setting level may require quite high salaries to stay working at the agency. Otherwise, the attrition rate will be very high.
} 
constraint, Eq. (5) was not satisfied), or they become "organisation men" who are loyal to the organization, thereby strengthening the system of organizational authority, and also adjusting their own professional norm towards the organization's goal. Kingston argues that, as time passes, selection for promotion of the most cautious and career-minded individuals tighten the bureaucratic organization's hierarchical structure. Risky endeavours become gradually eliminated and the organization becomes standardised in order to limit uncertainty. (Kingston 2002, pp. 202-203). Under these circumstances it seems unrealistic to expect much convergence of the agenda-setting optimum towards the social optimum.

We now understand why it may not be in the bureaucrats' interest to conduct a BCA and have a better understanding of the rents arising from the bureaucrats' preferences and of the dynamics of the organization. We now turn to the question of why some public agencies in certain policy areas nevertheless conduct BCAs and why others do not.

\section{The Impact of a Governmental Budget Constraint}

Having explained why bureaucrats may be reluctant to do a $\mathrm{BCA}$, the question that remains is why a BCA is nevertheless used in some policy areas. In Sweden this is the case for transport infrastructure investments and with regard to the prices and subsidies paid for medicines, but not for environmental, energy and climate change policy (Hultkrantz 2009; also see the discussion in Sect. 1).

One factor that differs between the policy areas where a BCA is regularly made, and those where it is not used, is their impact on the state budget. Both transport infrastructure and subsidies for medicines are considerable expenditures for the Swedish state. Environmental, energy and climate change policies, on the other hand, are mainly paid for by the general public and enterprises, and do not influence the government's budget much. Indeed, some policy instruments, such as the carbon dioxide tax, actually generate revenue for the state, while others, such as the green electricity certificate scheme, are designed to be revenue-neutral from the State's point of view.

For this reason, in this section, we shortly model and discuss the bureaucrats' policy choice and incentives for doing a BCA when they act under a binding budget constraint. Assume, that for whatever reason, the government's ability to tax the citizens and to provide the public good is limited to $c^{g}(g) \leq \widehat{c}$. The socially optimal supply of the public good is then obtained by maximizing Eq. (2) subject to the constraint. Denoting the shadow price of the constraint by $\lambda$, the socially optimal level of public good provision is obtained from:

$$
\begin{aligned}
Q_{g}(g) & =(1+\lambda) c_{g}^{g}(g) \\
c^{g}(g) & =\hat{c} .
\end{aligned}
$$

Because we have assumed the benefits from public good consumption to be concave in $g$, the restriction lowers the provision of the public good. This is because the cost side of Eq. (9), including the shadow price of the public good provision, is higher than in the absence of a restriction.

We analyze the incentives to conduct a BCA with the help of Fig. 3. Figure 3 is similar to Fig. 2 except for the inclusion of the budget constraint, denoted by the thick black line $\hat{g}$.

We start by noting that a budget constraint, in order to be binding, must restrict the supply of the public good below the socially optimal level. Secondly, the budget constraint does not bind if the goal level of policy lies below it; in this case the bureaucrats prefer a lower level of public good provision than the budget constraint and the analysis in Sect. 3.1 


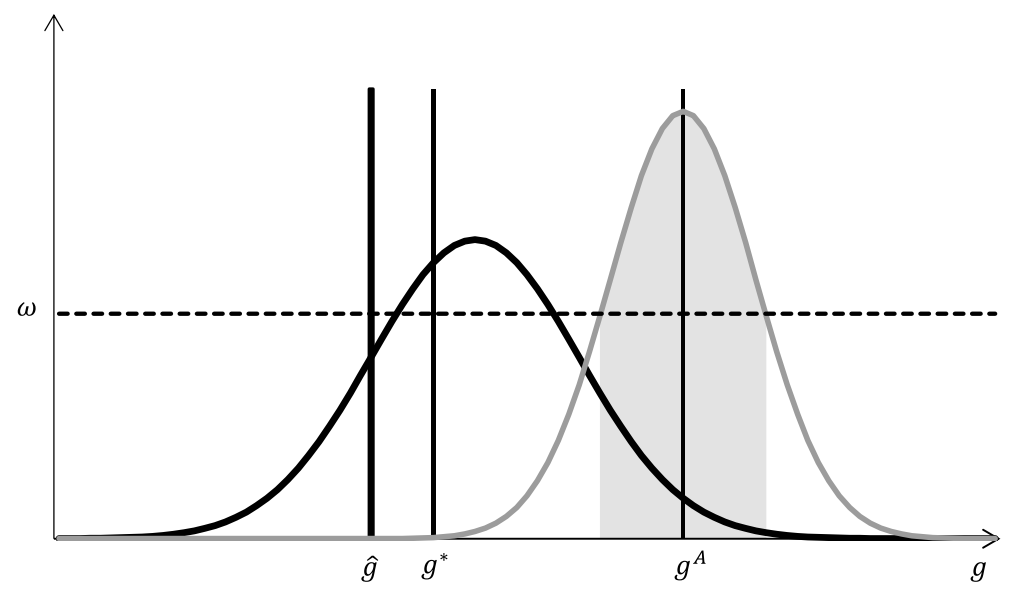

Fig. 3 Incentives for doing a BCA in the presence of a governmental budget constraint

holds. Therefore, the situation drawn in Fig. 3, where the budget constraint lies both below the social optimum and the agenda-setting level of public good provision is the only interesting one.

In a situation like the one depicted in Fig. 3, bureaucrats always have an incentive to conduct a BCA if a BCA can influence the budget constraint. It is then in the bureaucrats' interests to demonstrate to the budget-setter that the public good is of more value to the citizens than its present level of supply, since the socially optimal level of provision lies closer to the bureaucrat's optimum than the budget constrained one. If, however, the public good is of the type "reduced pollution through polluters' abatement", "consumer-paid subsidies to the production of certain goods" (e.g., feed-in tariffs, a Green certificate system) etc., where the private sector pays for the provision of the public good, such an incentive does not exist. Instead, it would be in the private sector actors' interest to challenge a stricter-than-optimal policy, e.g., in court. This is commonly done in the US but very rarely in Sweden - in fact, it seems that the main challenge to costly environmental regulations in Europe comes from protests, such as the gilet jaune -protests in France, or the related bensinupproret (gasoline rebellion) in Sweden. ${ }^{12}$

Some empirical evidence for the impact of a budget constraint on bureaucrats use of BCA can be found in Hammes et al. (2021). The authors conducted a choice experiment, asking bureaucrats at five Swedish government agencies (the Environmental Protection Agency (SEPA), the Energy Agency, Transport Administration (STA), Transport Agency, and Transport Analysis) to choose between five policy options, two of which could be costefficient depending on assumptions of parameter values. The impact of a budget constraint was studied in two ways: by analyzing responses from each agency separately, with STA regularly working under a budget constraint that limits the agency's ability to provide a public good while the SEPA does not, and by including a reminder of a governmental budget constraint into half of the surveys. The results indicate that the reminder had a statistically significant impact on the responses by SEPA bureaucrats while it did not have any impact on the responses by bureaucrats at the STA.

12 The author thanks an anonymous referee for helping to clarify this issue. 


\section{Discussion and Conclusions}

We set out to study why a BCA is most often not made by bureaucrats engaged in environmental, energy and climate change policymaking in Sweden (Swedish Environmental Protection Agency 2020). Taking a goal level of policy, which differs from the socially optimal level of public good provision, as given, and combining it with fixed wages, we show that bureaucrats will self-select to work at a governmental agency. Those bureaucrats whose professional norms lie close to the goal (agenda-setting) level of public good provision earn economic rents, while the marginal bureaucrat earns their reservation wage. Bureaucrats with more deviating preferences compared to the marginal bureaucrat are uninterested in staying employed by the agency because of the high search, cognitive adjustment and cognitive dissonance costs, and they quit. From an employer's point of view a given salary level then limits the possibilities to hire people who "think differently", which may lead to group-think within public agencies.

We also show how the goal level of public good provision may well be quite stable. This is because of three impacts. The first arises because of the cognitive adjustment which is assumed to take place. Over time, the marginal bureaucrat's professional norm will approach the goal level, given that they have not decided to quit first. Secondly, the agency's promotion policy may well support a stable equilibrium policy level. Finally, however, because of the distribution of preferences in the general public, and because the bureaucrats are drawn from this population, the likelihood of employing a marginal bureaucrat closer to the population mean may be higher than the probability of employing somebody with more deviant professional norms. This exerts an influence on the goal level of public good provision over time, to move in the direction of the mean policy, i.e., towards the point with the highest density of the public's distribution of preferences for public good provision. The mean policy may or may not be equal to the socially optimal policy, depending on the cost of the policy. Nevertheless, the bureaucrats at no time have any incentives to do a BCA. Once the initial goal level of policy is set, it is very difficult to change.

Finally, we show that in the presence of a governmental budget constraint, the bureaucrats at the governmental agency have an incentive to conduct a BCA given that their preferences for the level of public good provision exceed the level imposed by the budget constraint. This may explain the use of BCA in areas such as transport infrastructure and prices and subsidies paid for medicines, which have direct negative budgetary consequences. In environmental, energy and climate change policy the costs are most often borne by the citizens and private companies, not by the state. A BCA would make these costs visible to the bureaucrats (and/or the decision-makers), who however prefer conducting policy based on their professional norms (or ideology in the case of politicians) which correspond to the goal level of public good provision.

Our results relate to several of the observations made by Mouter (2017a) who interviewed Dutch decision-makers and draw conclusions about why they were reluctant to use BCA when forming their opinion. First, if the decision-makers' professional norms coincide with the goal policy level, they may well consider the process of forming an opinion a trivial one (Mouter's point 1). Similarly, such a decision-maker will likely exhibit a low level of trust in the BCA (Mouter's point 3), which contradicts both with their own professional norm and the goal level of policy, and will consequently contest the normative premises implicit in a BCA (Mouter's point 4) and see the explanatory power of a BCA as limited (Mouter's point 5). Finally, as demonstrated in Sect. 4, the social profitability of a policy is of a lesser concern when money is plentiful (Mouter's point 7). 
The model in the present paper is based on a number of assumptions. The first is that a bureaucrat can have real authority, that is, that they can influence the agency's policy recommendations. That this is the case in Sweden is demonstrated, e.g., by Uba (2010), who show that the representation of governmental agencies (bureaucrats, experts) in governmental commissions is considerable (for Germany, see Faber et al. (2002), for the US, Berkowitz and Krause (2020)). Uba's conclusions apply for energy and environmental (climate) policy. The model in the present paper lacks in realism, however, in that it studies the incentives of single bureaucrats. In reality, public policy decisions are usually made by groups of people. Game-theoretic analyses might yield more insights but are beyond the scope of the present paper. Moreover, we have assumed normally distributed preferences with regard to public good consumption. Assuming a different distribution of preferences might also yield additional insights. The form of the public good utility function is standard to the literature.

Examples of the kinds of problems illuminated by the preset paper are given in the choice experiment study by Carlsson et al. (2011), in Eggert et al. (2018), and in Uba (2010). Carlsson et al. (2011) survey a random sample of Swedish citizens and a random sample of administrators working at the Swedish Environmental Protection Agency (SEPA) with regard to preferences towards two environmental quality objectives, a balanced marine environment and clean air. The authors asked the SEPA administrators to choose the alternatives they would recommend as a policy, while the citizens were asked to act as private persons. The study finds, among other, that SEPA administrators have a higher willingness to pay for five out of the seven attributes that questions were asked about, and that the difference may not only be significant but also substantial. The administrators motivate their choices with concerns for ecological sustainability. These findings corroborate those in Uba's study. She notes that despite the "Swedish corporatist traditions" and the weak representation of renewable energy producers, the Swedish renewable-energy policies can be characterized as "forerunner" and "pioneering". Her explanation of this is the significant presence of environmental interests among agents of the state, who dominate the process of policy assessment in the commissions of inquiry preceding policy decisions, i.e., that the members and experts who represent the ministries and state agencies often champion environmental interests, while the role of scientists (including economists) is quite limited; see also Lindvall and Rothstein (2006) for an analysis of ideological state apparatuses in Sweden.

Finally, Eggert et al. (2018) also study the bureaucrats at the SEPA and compare their preferences to those of the general public and members of a special interest group. They show, among others, that if the respondents are asked to answer one question as private citizens and another as administrators, the order in which the questions are posed influences the answers. We take this as preliminary evidence for the impact of cognitive dissonance, i.e., it is an attempt by the respondent to answer in a consistent manner (Johansson-Stenman \& Svedsäter 2008).

Acknowledgements The author thanks two anonymous reviewers, Lena Nerhagen, and the participants of the SBCA: European Conference 2019 for useful comments.

Funding Open access funding provided by Swedish National Road and Transport Research Institute (VTI).

\section{Declarations}

Conflict of interest This study was funded by the Swedish Energy Agency. The author has no relevant financial or non-financial interests to disclose. 
Open Access This article is licensed under a Creative Commons Attribution 4.0 International License, which permits use, sharing, adaptation, distribution and reproduction in any medium or format, as long as you give appropriate credit to the original author(s) and the source, provide a link to the Creative Commons licence, and indicate if changes were made. The images or other third party material in this article are included in the article's Creative Commons licence, unless indicated otherwise in a credit line to the material. If material is not included in the article's Creative Commons licence and your intended use is not permitted by statutory regulation or exceeds the permitted use, you will need to obtain permission directly from the copyright holder. To view a copy of this licence, visit http://creativecommons.org/licenses/by/4.0/.

\section{References}

Acharya A, Blackwell M, Sen M (2018) Explaining preferences from behavior: a cognitive dissonance approach. J Polit 80(2):400-411

Acharya A, Blackwell M, Sen M (2015) Explaining attitudes from behavior: a cognitive dissonance approac. Harvard Kennedy School RWP15-026

Aghion P, Tirole J (1997) Formal and real authority in organizations. J Polit Econ 105(1):1-29

Akerlof GA, Dickens WT (1982) The economic consequences of cognitive dissonance. Am Econ Rev 72(3):307-319

Alesina A, Tabellini G (2007) Bureaucrats or politicians? Part I: a single policy task. Am Econ Rev 97(1):169-179

Alfnes F, Yue C, Jensen HJ (2010) Cognitive dissonance as a means of reducing hypothetical bias. Eur Rev Agric Econ 37(2):147-163

Annema JA, Frenken K, Koopmans C, Kroesen M (2017) Relating cost-benefit analysis results with transport project decisions in the Netherlands. Lett Spat Resour Sci 10:109-127

Berkowitz D, Krause G (2020) How bureaucratic leadership shapes policy outcomes: Partisan politics and affluent citizens' incomes in the American states. J Publ Policy 40(2):305-328

Besley T, Ghatak M (2005) Competition and incentives with motivated agents. Am Econ Rev 95(3):616-636

Bondemark A, Sundbergh P, Tornberg P, Brundell-Freij K (2020) Do impact assessments influence transport plans? The case of Sweden. Transp Res Part A 134:52-64

Brady GL, Clark JR, Davis WL (1995) The political economy of dissonance. Public Choice 85(1-2):37-51

Broberg T, Samakovlis E, Forslund J (2010) Investeringsstöd - ett överskattat styrmedel i miljöpolitiken. Ekon Debatt 38(3):17-26

Brösamle KJ, Norström Skans O (2011) Paths to higher office: evidence from the Swedish Civil Service, Uppsala: IFAU Working Paper 2011:13

Carlsson F, Kataria M, Lampi E (2011) Do EPA administrators recommend environmental policies that citizens want? Land Econ 87:60-74

Dewatripont M, Jewitt I, Tirole J (1999) The economics of career concerns, part II: application to missions and accountability of government agencies. Rev Econ Stud 66:199-217

Eggert H, Kataria M, Lampi E (2018) Difference in preferences or multiple preference orderings? Comparing choices of environmental bureaucrats, recreational anglers, and the public. Ecol Econ 151:131-141

Eliasson J, Lundberg M (2011) Do cost-benefit analyses influence transport investment decisions? Transp Rev 32:29-48

Faber M, Petersen T, Schiller J (2002) Homo oeconomicus and homo politicus in Ecological Economics. Ecol Econ 40:323-333

Festinger L (1957) A theory of cognitive dissonance. Stanford University Press, Stanford, CA

Forsstedt S (2018) Tänk efter före! En ESO-rapport om samhällsekonomiska konsekvensanalyser, Stockholm: Expertgruppen för Studier i Offentlig ekonomi 2018:5

Gregg P et al (2011) How important is pro-social behaviour in the delivery of public services? J Public Econ 95:758-766

Hahn RW, Tetlock PC (2008) Has economic analysis improved regulatory decisions? J Econ Perspect 22(1):67-85

Halse AH, Fridstrøm L (2019) Explaining low economic return on road investments. New evidence from Norway, Oslo: MPRA Paper No. 94389

Hammes JJ, Nerhagen L, Fors HC (2021) The influence of individual characteristics and institutional norms on bureaucrats' use of cost-benefit analysis: a choice experiment. J Benefit Cost Anal 12(2):258-286

Hansson L, Nerhagen L (2019) Regulatory measurements in policy coordinated practices: the case of promoting renewable energy and cleaner transport in Sweden. Sustainability 11(6):1687 
Hansson L (2019) Public administrators' roles in the policy adaptation of transport directives: how knowledge is created and reproduced. Transp Policy 98:208-216

Hultkrantz L (2009) Ett Styvbarn. Ekon Debatt 37(7):3-5

Johansson-Stenman O, Svedsäter H (2008) Measuring hypothetical bias in choice experiments: the importance of cognitive consistency. B.E. J Econ Anal Policy 8(1)

Kingston W (2002) A running repair for the civil service. Polit Q 2:198-207

Konow J (2000) Fair shares: accountability and cognitive dissonance in allocation decisions. Am Econ Rev 90(4):1072-1091

Lindvall J, Rothstein B (2006) Sweden: the fall of the strong state. Scand Polit Stud 29(1):47-63

Meyer JP, Allen NJ, Smith CA (1993) Commitment to organizations and occupations: extension and test of a three-component conceptualization. J Appl Psychol 78(4):538-551

Mouter N (2017a) Dutch politicians' use of cost-benefit analysis. Transportation 44:1127-1145

Mouter N (2017b) Dutch politicans' attitudes towards cost-benefit analysis. Transp Policy 54:1-10

Mouter N, Annema JA, van Wee B (2013) Attitudes towards the role of cost-benefit analysis in the decisionmaking process for spatial-infrastructure projects: a Dutch case study. Transp Res Part A 58:1-14

Nail PR, Misak JE, Davis RM (2004) Self-affirmation versus self-consistency: a comparison of two competing self-theories of dissonance phenomena. Personal Individ Differ 36:1893-1905

Nerhagen L, Forsstedt S (2019) Should regulatory impact assessment have a role in sweden's transport planning. ITF Roundtable, Paris

Nyborg K (1998) Some Norwegian politicians' use of cost-benefit analysis. Public Choice 95(3-4):381-401

Polidori P, Teobaldelli D (2013) Prosocial behavior in the production of publicly provided goods and services: an overview. Int Rev Appl Econ 27(2):285-296

Pyddoke R, Nerhagen L (2010) Miljöpolitik på samhällsekonomisk grund. En fallstudie om styrmedlet miljökvalitetsnormer för partiklar och kvävedioxid, Linköping

Rose-Ackerman S (2007) Public choice, public law and public policy. Keynote address, First World Meeting of the Public Choice Society, Amsterdam

Rothstein B (2016) Epistemic democracy, corruption and human well-being. In: Pisa: Paper presented at the European Consortium for Political Research - Joint Session of Workshops, April 25-29

Sager TØ (2016) Why don't cost-benefit results count for more? The case of Norwegian road investment priorities. Urban Plan Trans Res 4(1):101-121

Sager TØ, Ravlum I-A (2005) The political relevance of planners' analysis: the case of a parliamentary standing committee. Plan Theory 4(1):33-65

Samakovlis E, Vredin Johansson M (2005) Samhällsekonomiskt underlag i miljöpolitiken: brister och förbättringar. Ekon Debatt 7:30-39

Samakovlis E, Vredin Johansson M (2007) En soppa med Klimp? Utvärdering av kostnadseffektiviteten i klimatinvesteringsprogrammen. Ekon Debatt 7:31-43

Shapiro S (2017) Structure and process: Examining the interaction between buraucratic organization and analytical requirements. Rev Policy Res 34(5):682-699

Sunstein C (2000) Cognition and benefit-cost analysis. J Legal Stud 29(2):1059-1103

Sunstein C (2019) Is cost-benefit analysis a foreign language? Q J Exp Psychol 72(1):3-7

Suzuki K, Hur H (2020) Bureaucratic structures and organizational commitment: findings from a comparative study of 20 European countries. Public Manag Rev 22:877-907

Swedish Environmental Protection Agency (2020) Samhällsekonomiska analyser inom miljömålsarbetet - en kartläggning av analyser. Naturvårdsverket Rapport 6935, Sweden

Uba K (2010) Who formulates renewable-energy policy? A Swedish Example. Energy Policy 38(11):6674-6683

Vigren A, Ljungberg A (2018) Public transport authorities' use of cost-benefit analysis in practice. Res Transp Econ 69:560-567

Welde M, Eliasson J, Odeck J, Börjesson M (2013) Planning, analytic tools and the use of cost-benefit analysis in the transport sector in Norway and Sweden. Concept Research Programme, Trondheim

Wichardt PC (2012) Norms, cognitive dissonance, and cooperative behaviour in laboratory experiments. Int J Soc Econ 39(5):342-356

Wilson JQ (1989) Bureaucracy. What government agencies do and why they do it. Basic Books Inc, United States of America

Publisher's Note Springer Nature remains neutral with regard to jurisdictional claims in published maps and institutional affiliations. 